\title{
USDA 846-1 Fractal Melon and Derived Recombinant Inbred Lines
}

Jack E. Staub ${ }^{1}$

U.S. Department of Agriculture, Agricultural Research Service, Forage and Range Research Laboratory, Utah State University, Logan, UT 84322-6300

\section{James D. McCreight}

U.S. Department of Agriculture, Agricultural Research Service, U.S. Agricultural Research Station, 1636 East Alisal, Salinas, CA 93905

\section{Juan E. Zalapa}

U.S. Department of Agriculture, Agricultural Research Service, Vegetable Crops Research Unit, Department of Horticulture, University of Wisconsin, 1575 Linden Drive, Madison, WI 53706

Additional index words. Cucumis melo, genetic distance, vegetable breeding

Genes residing in highly branched, fractal melons [Cucumis melo ssp. agrestis (Naud.) Pangalo] have the potential for increasing yield in dessert melon types, C. melo L. ssp. melo (Zalapa et al., 2006). A horticulturally unique $C$. melo ssp. agrestis germplasm, designated CR1 (Fig. 1), was received in 1995 from Mr. Claude Hope, Cartago, Costa Rica, by the USDA-ARS Cucumber and Melon Breeding Project, Madison, WI. The earlyflowering (in Wisconsin), monoecious CR1 is rapid-growing, indeterminate and bears many (up to 100 fruits/plant) small (3 to $6 \mathrm{~cm}$ in diameter) (Staub et al., 2004; Zalapa, 2005; Zalapa et al., 2006) fruits on an indeterminate, highly branched (six to 12 primary branches) plant with standard length internodes, i.e., not compact, si (Denna, 1962; Paris et al., 1984). The architectural type of CR1 is unique and distinct from vining (Rosa, 1924), dwarf (Denna, 1962; Mohr and Knavel, 1966), and birdnest (Paris et al., 1981, 1982, 1984) plant habits, and thus, is designated here as a "fractal" type (Prusinkiewicz and Lindenmayer, 1990) because of its highly branched, radiant growth habit when compared with standard vining phenotypes such as 'Top Mark' (Fig. 1). The fractal architecture of CR1 is, thus, a function of its internode length and comparatively high numbers of primary, secondary, and tertiary branches (Zalapa, 2005).

This report describes the highly branched, fractal-type melon USDA 846-1 line and 81 derived recombinant inbred lines (RIL) that

\footnotetext{
Received for publication 18 Jan. 2011. Accepted for publication 25 Mar. 2011.

Mention of a trade name, proprietary product, or specific equipment does not constitute a guarantee or warranty by the USDA and does not imply its approval to the exclusion of other products that may be suitable.

${ }^{1}$ To whom reprint requests should be addressed; e-mail jack.staub@ars.usda.gov.
}

deployment of marker-assisted selection for quantitative traits associated with fruit yield and quality.

\section{Origin}

Line USDA 846-1. In 1995, a horticulturally unique Cucumis melo ssp. agrestis (Naud.) Pangalo germplasm designated CR1 was received by the USDA-ARS, Madison, WI. The fractal habit of CR1 was transferred into elite melon (C. melo) germplasm by crossing it with an $\mathrm{F}_{1}$ plant from a cross of FMR\#3 $\times$ SC\#6. Breeding line FMR\#3 is an $\mathrm{F}_{3}$ selection from the cross Galia $\times$ Qalya (Paris et al., 1989) and may be characterized as C. melo var. inodorus. Breeding line SC\#6 was an $\mathrm{S}_{5}$ from a complex cross of Eastern U.S. market-type melons (C. melo var. reticulatus) selected by Perry E. Nugent (retired, USDA-ARS, U.S. Vegetable Laboratory, Charleston, SC) for germinability at low temperature. A monoecious, early-flowering (Wisconsin) plant was chosen from this threeway cross and self-pollinated four generations with concomitant selection for branching, earliness, and monoecy to produce an $\mathrm{S}_{4}$ line designated USDA 846-1. Fruit of this line are slightly netted, non-ribbed, and typically ovoid (Fig. 1).

Derived recombinant inbred lines. A set of 81 recombinant inbred lines $\left(\mathrm{F}_{7}\right)$ was

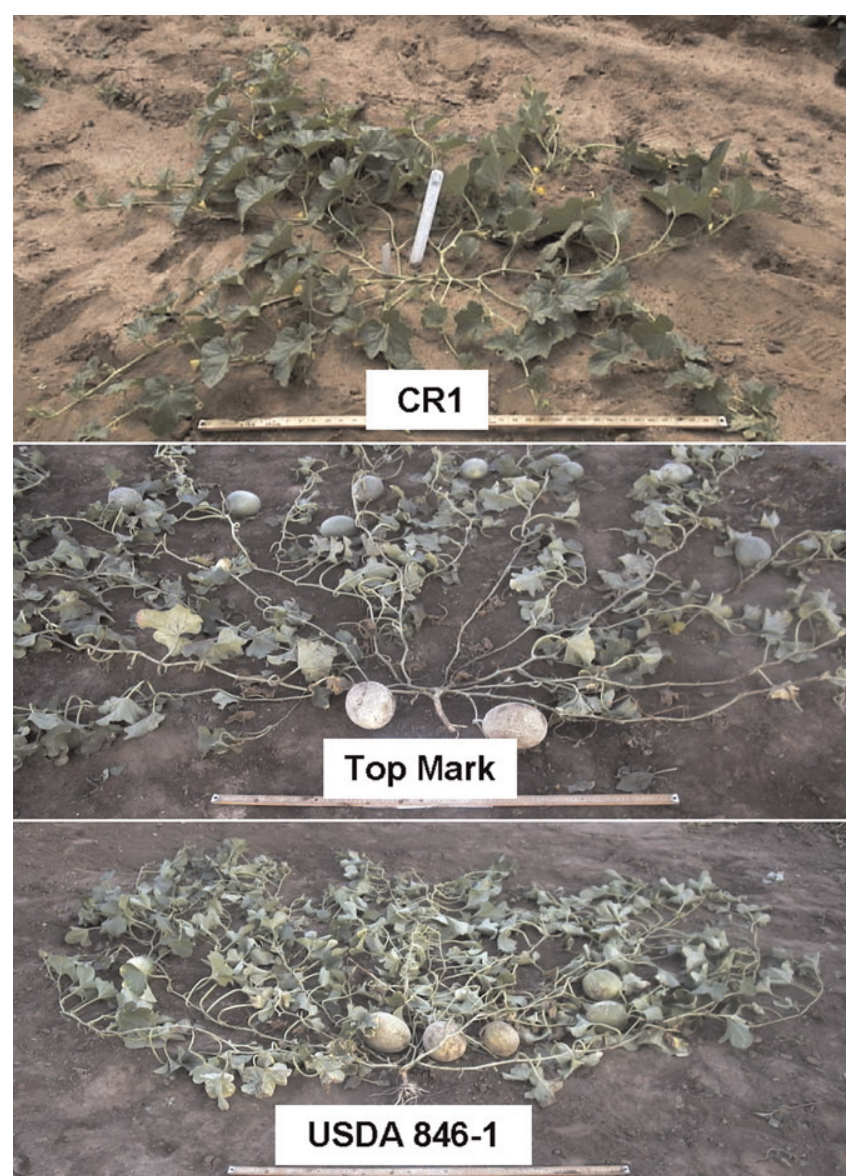

Fig. 1. Vegetative growth habit, branching, and fruit-set patterns in melon (Cucumis melo L.) germplasm CR1, 'Top Mark', and USDA 846-1. 
Table 1. Best linear unbiased estimations (BLUE) of USDA 846-1 ( $\left.\mathrm{P}_{1}\right)$, ‘Top Mark' $\left(\mathrm{P}_{2}\right)$, ‘Esteem' (ES), 'Sol Dorado' (SD), 'Hale's Best Jumbo' (HB), and best linear unbiased predictions (BLUP) of a melon RIL population and their SES and $95 \%$ confidence intervals (CIs) for yield and fruit quality components of plants grown at Hancock, WI, and El Centro, CA, in 2002 and 2004. ${ }^{\mathrm{z}}$

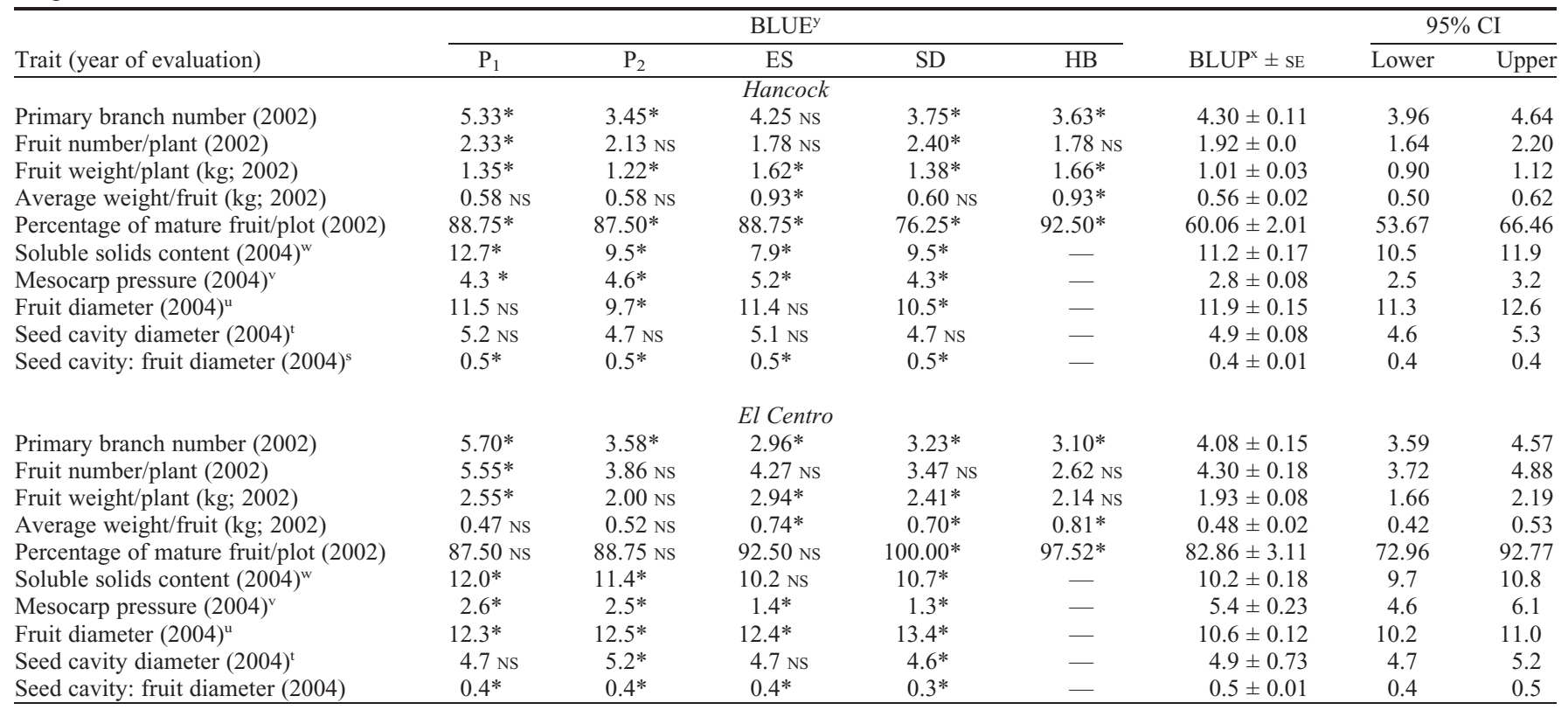

${ }^{\mathrm{z}}$ Data abstracted from Paris et al. (2008) and Zalapa et al. (2008).

${ }^{\mathrm{y}_{\mathrm{NS}}}=$ The BLUE of the a parental line, their hybrid, and/or 'Hales Best Jumbo' for yield components are considered not significantly different $\left(P_{0.05}\right)$ from the average of the RIL when values were within the CI limit of the RIL population BLUP.

x* Significantly different $\left(P_{0.05}\right)$ from the average of the RIL when values were outside the CI limit of the RIL population BLUP.

${ }^{\text {w} M e l o n ~ f r u i t ~ f r o m ~ e a c h ~ e n t r y ~ w e r e ~ a n a l y z e d ~ f o r ~ t o t a l ~ s u g a r ~ u s i n g ~ a ~ d i g i t a l ~ B R I X ~ r e f r a c t o m e t e r ~(M o d e l ~ D R 103 L ; ~ Q A ~ S u p p l i e s, ~ N o r f o l k, ~ V A) . ~}$

${ }^{\mathrm{V}} \mathrm{Punch}$ test at stem end and blossom end using a penetrometer with a $0.79 \mathrm{~cm}$ tip (Model \# FT 011; Effigi, Alfonsine, Italy).

"Melon fruit cut horizontally for fruit diameter measurement.

${ }^{\text {t}}$ Seed cavity diameter measured at the center-most portion of horizontally sectioned fruit.

developed from a cross between USDA 8461 and Western shipping type 'Top Mark' using single-seed descent from a single $F_{1}$ plant (Zalapa, 2005; Zalapa et al., 2008).

\section{Description}

The indeterminate, monoecious USDA 8461 produces two to five concentrated crownset fruit on a highly branched (five to eight primary branches) fractal architectural habit and is capable of multiple fruiting cycles at a commercial spacing $(0.35 \mathrm{~m}$ within-row spacing on 2-m center; 72,600 plants/ha) (Zalapa, 2005). Primary branch number and concentrated fruit set is higher than 'Top Mark', 'Hale's Best Jumbo', 'Esteem', and 'Sol Dorado', as evaluated in Hancock, WI, and El Centro, CA (Table 1) (Zalapa, 2005; Zalapa et al., 2006, 2008). The fruit quality characteristics (exterior and interior quality, sugar content, $\beta$-carotene content) of USDA 846-1 tend to be inferior to these commercial varieties (Cuevas et al., 2008; Paris et al., 2008).

RIL derived from a USDA 846-1 $\times$ 'Top Mark' mating possess different vegetative, flowering, and fruit characteristics. Some individual RIL transgress the performance of either parent or control commercial cultivars (above) for primary branch number, fruit number per plant, fruit weight per plant, average weight per fruit, percentage of mature fruit per plot, soluble solids content, mesocarp pressure, fruit diameter (mesocarp + exocarp), seed cavity diameter (endocarp), seed cavity to fruit diameter ratio, fruit shape, percentage of exocarp netting, and $\beta$-carotene (Table 1) (Cuevas et al., 2008; Paris et al., 2008; Zalapa et al., 2008). The $\beta$-carotene content in fruit of these RIL, which ranged from 8.1 to $22.3 \mu \mathrm{g} \cdot \mathrm{g}^{-1}$ fresh weight (FW) in California and from 3.7 to $24.4 \mu \mathrm{g} \cdot \mathrm{g}^{-1} \mathrm{FW}$ in Wisconsin, also differs considerably from the parental means (USDA 846-1 = 13.0 and 9.9 $\mu \mathrm{g} \cdot \mathrm{g}^{-1} \mathrm{FW}$ and 'Top Mark' = 11.9 and 14.7 $\mu \mathrm{g} \cdot \mathrm{g}^{-1} \mathrm{FW}$, respectively, in California and Wisconsin). Fruit of the RIL are slight to variable for fruit shape (oblate, ovoid, or round), heavily netted, and can be slightly ribbed (vein tracts). Inheritance of these traits is complex and expression predictably is affected by growing environment (e.g., soil type and climatic conditions, plant spacing, etc.; Zalapa et al., 2008). For example, overall melon productivity (e.g., fruit number and weight) was considerably different across growing locations, but productive genotypes remained consistent regardless of locations. Quantitative trait loci and genetic marker associations have been characterized for all the traits mentioned here and provide the opportunity for deployment of marker-assisted selection during plant improvement of elite germplasm.

\section{Availability}

Seed of 846-1 and the 81 derived RILs from a hand-pollinated greenhouse increase may be obtained by written request to J.D. McCreight (jim.mccreight@ars.usda.gov).

\section{Literature Cited}

Cuevas, H.E., J.E. Staub, P.W. Simon, J.E. Zalapa, and J.D. McCreight. 2008. Mapping of genetic loci that regulate quantity of beta-carotene in fruit of US Western Shipping melon (Cucumis melo L.). Theor. Appl. Genet. 117:1345-1359.

Denna, D.W. 1962. A study of the genetic, morphological and physiological basis for the bush and vine habit of several cucurbits. $\mathrm{PhD}$ thesis, Cornell Univ., Ithaca, NY.

Mohr, H.C. and D.E. Knavel. 1966. Progress in the development of short-internode (bush) cantaloupes. HortScience 1:16.

Paris, H.S., Y. Burger, H. Nerson, and M. Edelstein. 1989. Qalya-A new muskmelon hybrid for export. Hassadeh 69:434-435.

Paris, H.S., Z. Karchi, H. Merson, M. Edelstein, A. Govers, and D. Freudenberg. 1982. Further observations on 'birdsnest' muskmelons. $\mathrm{Cu}$ curbit Genet. Coop. Rpt.: 28.

Paris, H.S., Z. Karchi, H. Nerson, M. Edelstein, A. Govers, and D. Freudenberg. 1981. A new plant type in Cucumis melo L. Cucurbit Genet. Coop. Rpt. 4:24-26.

Paris, H.S., H. Nerson, and Z. Karchi. 1984. Genetics of internode length in melons. J. Hered. 75:403-406.

Paris, M.K., J.E. Zalapa, J.D. McCreight, and J.E. Staub. 2008. Genetic dissection of fruit quality components in melon (Cucumis melo L.) using a RIL population derived from exotic $\times$ elite US western shipping germplasm. Mol. Breed. 22: 405-419.

Prusinkiewicz, P. and A. Lindenmayer. 1990. The algorithmic beauty of plants. Springer-Verlag, New York, NY. 
Rosa, J.T. 1924. Fruiting habit and pollination of cantaloupes. Proc. Amer. Soc. Hort. Sci. 21:51-57.

Staub, J.E., J.E. Zalapa, M.K. Paris, and J.D. McCreight. 2004. Selection for lateral branch number in melon (Cucumis melo), p. 381-387. In: Lebeda, A. and H.S. Paris (eds.). Progress in cucurbit genetics and breeding research. Proc. of Cucurbitaceae
2004, the 8th EUCARPIA Meeting on $\mathrm{Cu}$ curbit Genetics and Breeding, Olomouc, Czech Republic, 12-17 July 2004. Palacky University in Olomouc.

Zalapa, J.E. 2005. Inheritance and mapping of plant architecture and fruit yield in melon (Cucumis melo L.). PhD diss., Dept. Horticulture, Univ. Wisconsin, Madison, WI.
Zalapa, J.E., J.E. Staub, and J.D. McCreight. 2006. Generation means analysis of plant architectural traits and fruit yield in melon. Plant Breed. 125:482-487.

Zalapa, J.E., J.E. Staub, and J.D. McCreight. 2008. Variance component analysis of plant architectural traits and fruit yield in melon. Euphytica 162:129-143. 